\title{
Productivity Improvement of Filter Drier Manufacturing Using Time Study
}

\author{
R. Jayachitra ${ }^{1}$, R. Rajesh ${ }^{2}$, P.Viswanathan ${ }^{3}$ \\ ${ }^{1,3}$ Associate Professors, Department of Mechanical Engineering, PSG \\ College of Technology ${ }^{2}$ PG Scholar, Department of Mechanical Engineering, \\ PSG College of Technology, India. \\ rjr.mech@psgtech.ac.in ${ }^{1}$,rajesman@gmail.com², pvn.mech@psgtech.ac.in ${ }^{3}$
}

\begin{abstract}
Productivity improvement is critical for any business because it has an effect on output and profits. The purpose of this paper is to examine the implementation of industrial engineering tools in a company that manufactures filter driers. This study begins by reading standard operating procedures and analysing the process flow in order to gain a comprehensive understanding of how to filter driers. Simultaneously, observations were made on the production line to ascertain the existence of any problems. The primary issue addressed in this study was a deviation in working hours from the standard. As a result, the manufacturing company's productivity decreased. This research examined and sought out potential solutions and alternatives aimed at achieving the objective through the use of motion and time-related tools. In aggregate, the suggested alternatives resulted in an expected increase in production capacity of $174.8 \%$.
\end{abstract}

Keywords: Productivity, Method Study and Time Study.

\section{Introduction}

Motion and time analysis requires an understanding of how an operation is carried out when a new product is created or an existing process is improved. Approaching any problem logically and methodically involves the following steps: Problem definition and analysis; search for potential solution; evaluation and discussion of alternative solutions; and recommendation for action are all included in this process. Repetitive production tasks, which can be monotonous, boring, exhausting, and demoralising, have a high priority for management in terms of employee satisfaction and productivity (Shikdar and Das, 2003).

Throughout history, there has been an accumulation of knowledge that has been geared toward enhancing the productivity of an organization and its employees. Goals in motion and time study are to eliminate redundant work and develop methods and procedures that are most effective, require the least effort, and are best suited to the user (Barnes, 1980; Meyers and Stewart, 2002).

The goal of this research was to determine how well a filter drier manufacturing company's work flow performed and how to make it run more efficiently. 


\section{Background And Review}

Productivity may be defined as follows:

Productivity $=$ Output/Input

It's possible for this definition to apply to an individual company, a specific industry, or the entire economy. When a system can extract a specific output from an input, the term "productivity" is used (Kanawaty, 1992). To put it another way, productivity can be thought of as the ratio of output to resources expended in order to generate that output.

Production resources, including raw materials and supplies, personnel, land, buildings, machines and equipment as well as energy are all factors that contribute to operational efficiency. Manufacturing, as we all know, relies on a variety of other resources in addition to labour. Gross domestic product (GDP) increases as a result of both an increase in the quantity of production factors (inputs) and an increase in productivity when discussing economic growth. As a result, productivity is seen as an important factor in economic growth (Galarneau and Dumas, 1993).

Working on streamlining or modifying a process in order to reduce the amount of time spent on completing a task, as well as the waste of resources, is the goal of a work study. As a result, it's obvious that productivity and work studies go hand in hand. If rearranging or simplifying the method of operation results in a 20 percent reduction in the time required to complete a specific task, then productivity increases by the same amount, or 20 percent. Methodological studies and work measurement studies are two types of work studies. It's a tool for systematically examining and improving human work practises by taking into account all of the variables that have an impact on productivity and working conditions. A time study can be conducted by recording all relevant information about the job, decomposing the job into elements, examining those elements and establishing the sample size, timing each element with a stopwatch, determining the worker's speed, converting the observed time to basic time, establishing allowances, and establishing the standard time after establishing a sample size and determining the sample size (Pisuchpen and Chansangar, 2014).

\section{Manufacturing Process For Filter Drier}

\section{FILTER DRIER}

The filter drier is a component used for the moisture adsorption of the refrigerants used in the cooling systems. Hence, as the application for the particular component is important in the cooling systems, the quality of the component is at most important. Similarly, to meet the customer requirement with the required quality the productivity of the company plays the major role in the market. The productivity of the filter drier component of the company should meet the customer requirements. Filter drier is mainly divided into two types. DML core type and DCL core type. DML cores $100 \%$ Molecular Sieve, DCL cores 70\% Molecular Sieve + $30 \%$ actuated alumina, DCL more resistant. Similarly the end connectors also vary for each component type requirement as mentioned by the customer. Four types of connector as Solder connector, Flare connector, Face seal connector, $\mathrm{Cu}$ - plated connector. 


\section{PROCESS FLOW OF FILTER DRIER MANUFACTURING}

Filter drier manufacturing consists of three set of different activities. 1) Washing and brazing, 2) Assembly and welding, 3) Packing. Before packing the required types of filter driers are given to third party painting and then final packing happens in the company.

\section{WASHING AND BRAZING}

Washing and brazing operation consists of the following activities. The below mentioned activities are done on the basic component, filter cup.

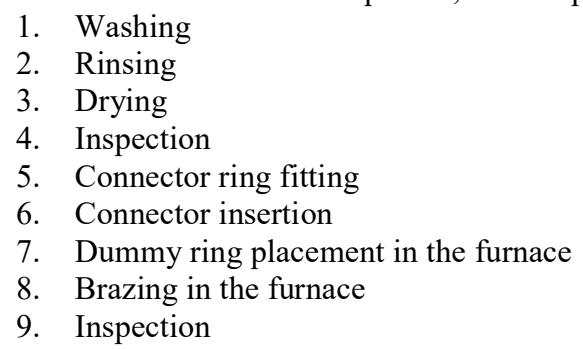

\section{FILTER DRIER ASSEMBLY PROCESS}

After the brazing process is completed, the main assembly of the filter cups along with the other sub-components are done. TIG and plasma welding is done on the filter cup assembly for leak free final component.

1. Filter cup part lassembly

2. Felt mat insertion

3. Perforated sheet insertion

4. Core punching

5. Filter cup part 2 assembly

6. Inspection

\section{WELDING AND LEAK TEST}

The assembled sub-assembly is now ready for welding and leak test. The following processes are done on the filter drier sub-assembly.
1. TIG welding
2. Inspection
3. Plasma welding
4. Inspection
5. Leak test
6. Inspection

\section{PACKING OPERATION}

Once the filter drier assembly is finished, it is sent to third party painting according the respective batches. After the painting process is done and received from the third party painting company, final packing process happens in the following flow.

1. Flare and connector cap fixing

2. Packing in separate boxes

3. Sticker pasting and silica gel insertion

4. Packing in industrial boxes 


\section{Outcome Of Literature Review}

A "Work Study" is a term that encompasses both methodological investigation and the measurement of labour. Gilberth's action study and Taylor's time study formed the basis of what would become the most important industrial engineering method ever devised. In order to boost output, lower costs, and improve the company's competitiveness, the most obvious characteristic is that less or no investment is required. As part of this, the company's operating methods are improved, work quotas are set at reasonable levels, and its resources are fully utilised. The study of methods and the quantification of work is known as a "work study." Working time quotas for each operating system are determined by the work measurement study, which focuses on determining the most efficient working method (Lan, et al., 2009). Work Study is a methodical approach to accomplishing a variety of distinct but related tasks, such as enhancing resource efficiency and establishing performance and quality standards for the activities to be performed. Method studies (Motion studies) and time studies (Work measurement) are the two main types of work studies (Kulkarni, et al., 2014). The primary goal of methodology is to find better ways of doing things. By eliminating inefficient processes, avoidable delays, and other waste, it adds value and improves efficiency.

\section{Objectives Of Research}

Observational data collection is used in this study. On a "preliminary study form," the times observed for specific work cycles and work elements are recorded alongside the expected times for each process element. Results are analysed; times measured are specified, and times measured multiplied by ratings to determine "base periods" after the timing process is complete. Base periods are used to calculate "representative period," and "standard time" is calculated by multiplying the shares by this base period. In-depth interviews with the plant manager and shift supervisor determine which employees will be included in the research. Participants in the timing study are chosen based on suggestions made by their managers and shift engineers for experienced workers who work at a balanced and average pace.

1. To increase the productivity of the filter drier according to the sales plan department requirement.

2. To improve the production plan by considering the before painting and after painting of filter drier

3. To reduce the inventory of the filter drier sub-components due to improper planning of the production order sequence.

\section{Methodology}

The following methodology is followed for the improvement of productivity in the filter drier manufacturing operation. 


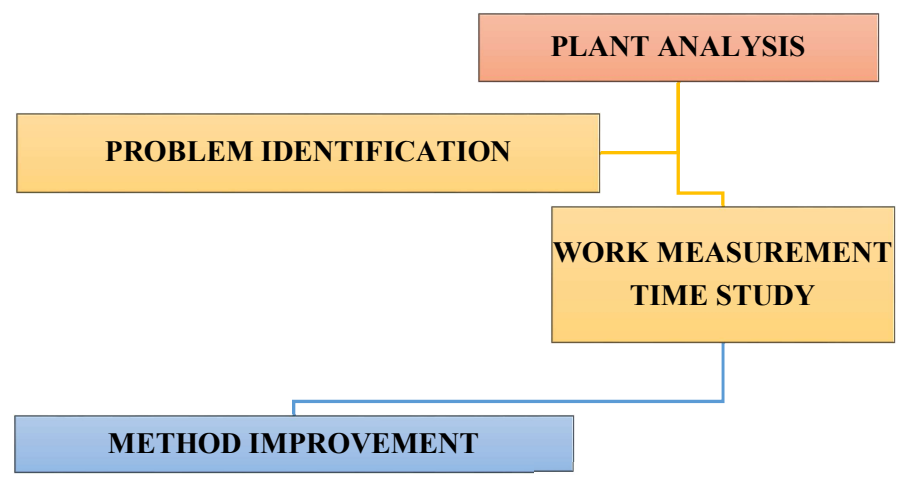

\section{PROBLEM INDENTIFICATION}

The plant analysis is done for the initial process and the main problem in the manufacturing company has been found out based on the following production data.

Figure 1. Production adherence of refrigeration and cooling components

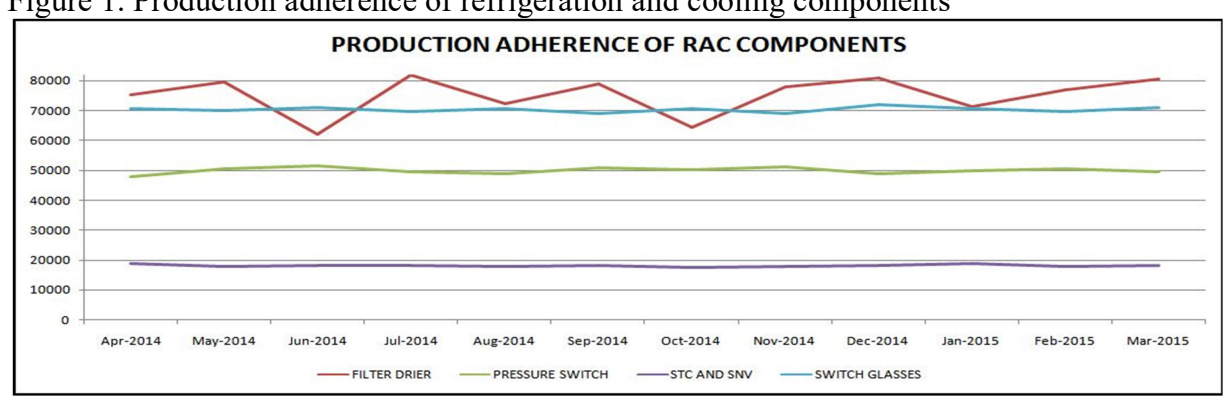

From the graph, it is evident that the productivity of the filter drier component in the refrigeration and cooling section is fluctuating when compared to the other components.

\section{Experimenation}

The purpose of the time study is to ascertain whether the manufacturing processes for filter driers adhere to efficiency principles. As such, our objective is to compare standard times obtained through "Time study" to actual process times in order to identify avoidable insufficient periods and to state preventative measures.

\section{Assumptions In Time Study}

The following assumptions are considered while conducting the study and assessing the results:

1. The number of observations determined represents the universe.

2. The rating is accurate and valid. 
3. The times measured with electronic stop watch are accurate and valid.

4. The time study's objective is to determine whether the manufacturing processes for filter driers follow efficiency principles. As such, our objective is to compare standard times obtained through "Time study" to actual process times in order to identify avoidable insufficient periods and to recommend corrective actions.

\section{Research Limitations}

Ratings are used to calculate the base period, which is a crucial step in achieving standard time values. Instantaneous evaluation of an object is possible when it is being observed. The most difficult part of the course is rating. "The difficulty in determining immediately which work pace is normal" is the most significant limitation of this study. Another problem is that when employees know they are being watched, they tend to work more slowly.

\section{Time Study}

Time study for the various activities in the manufacturing of filter driers have been conducted based on the following work hours in the filter drier manufacturing company norms.

Table 1. Work hours time table

\begin{tabular}{|c|c|c|c|c|c|c|c|c|c|c|c|c|c|c|c|}
\hline & \begin{tabular}{|l} 
5:00 \\
AM
\end{tabular} & $\begin{array}{l}\text { 6:00 } \\
\text { AM }\end{array}$ & $\begin{array}{l}\text { 7:00 } \\
\text { AM }\end{array}$ & $\begin{array}{l}7: 45 \\
\text { AM }\end{array}$ & $\begin{array}{l}\text { 8:00 } \\
\text { AM }\end{array}$ & $\begin{array}{l}\text { 8:00 } \\
\text { AM }\end{array}$ & $\begin{array}{l}\text { 9:00 } \\
\text { AM }\end{array}$ & & $\begin{array}{l}10: 00 \\
\mathrm{AM}\end{array}$ & $\begin{array}{l}11: 00 \\
\text { AM }\end{array}$ & $\begin{array}{l}12: 00 \\
\text { PM }\end{array}$ & $\begin{array}{l}12: 45 \\
\text { PM }\end{array}$ & $\begin{array}{l}\text { 1:00 } \\
\text { PM }\end{array}$ & $\begin{array}{l}\text { 1:00 } \\
\text { PM }\end{array}$ & $\begin{array}{l}\text { 2:00 } \\
\text { PM }\end{array}$ \\
\hline \multirow[t]{2}{*}{$\begin{array}{l}\text { 1ST } \\
\text { Shift }\end{array}$} & \multicolumn{3}{|c|}{ WORK HOURS } & \multicolumn{2}{|c|}{ BREAK } & \multicolumn{2}{|c|}{$\begin{array}{l}\text { WORK } \\
\text { HOURS }\end{array}$} & $\begin{array}{l}\text { BREAK } \\
\text { FAST }\end{array}$ & \multicolumn{3}{|c|}{ WORK HOURS } & \multicolumn{2}{|c|}{ BREAK } & \multicolumn{2}{|c|}{$\begin{array}{l}\text { WORK } \\
\text { HOURS }\end{array}$} \\
\hline & \begin{tabular}{|l|} 
2:00 \\
PM
\end{tabular} & $\begin{array}{l}\text { 3:00 } \\
\text { PM }\end{array}$ & $\begin{array}{l}\text { 4:00 } \\
\text { PM }\end{array}$ & $\begin{array}{l}4: 45 \\
\text { PM }\end{array}$ & $\begin{array}{l}5: 00 \\
\text { PM }\end{array}$ & $\begin{array}{l}\text { 5:00 } \\
\text { PM }\end{array}$ & $\begin{array}{l}\text { 6:00 } \\
\text { PM }\end{array}$ & & $\begin{array}{l}\text { 7:00 } \\
\text { PM }\end{array}$ & $\begin{array}{l}\text { 8:00 } \\
\text { PM }\end{array}$ & $\begin{array}{l}\text { 9:00 } \\
\text { PM }\end{array}$ & $\begin{array}{l}\text { 9:45 } \\
\text { PM }\end{array}$ & $\begin{array}{l}\text { 10:00 } \\
\text { PM }\end{array}$ & $\begin{array}{l}\text { 10:00 } \\
\text { PM }\end{array}$ & $\begin{array}{l}\text { 11:00 } \\
\text { PM }\end{array}$ \\
\hline $\begin{array}{l}\text { 2ND } \\
\text { Shift }\end{array}$ & \multicolumn{3}{|c|}{ WORK HOURS } & \multicolumn{2}{|c|}{ BREAK } & \multicolumn{2}{|c|}{$\begin{array}{l}\text { WORK } \\
\text { HOURS }\end{array}$} & DINNER & \multicolumn{3}{|c|}{ WORK HOURS } & \multicolumn{2}{|c|}{ BREAK } & \multicolumn{2}{|c|}{$\begin{array}{l}\text { WORK } \\
\text { HOURS }\end{array}$} \\
\hline
\end{tabular}

Table 2. First shift time study time table

\begin{tabular}{|c|l|l|l|}
\hline S.No & Activities & 30-01-2017 & 31-01-2017 \\
\hline 1 & Washing Machine feeding (Pallet to conveyor) & 5:00 AM to 6:00 AM & 5:00 AM to 6:00 AM \\
\hline 2 & Connector ring fitting and connector insertion on the cup & 6:00 AM to 7:00 AM & 6:00 AM to 7:00 AM \\
\hline 3 & Dummy Ring Placement & 7:00 AM to 7:06 AM & 7:00 AM to 7:06 AM \\
\hline 4 & Cups removal from the furance and placement in pallets & 8:00 AM to 9:00 AM & 8:00 AM to 9:00 AM \\
\hline 5 & Filter cups from pallet to fixture & & \\
\hline 6 & Wire mesh + Felt mat insertion & \multirow{2}{*}{ 7:10 AM to 7:45 AM } & \multirow{2}{*}{ 7:10 AM to 7:45 AM } \\
\hline 7 & Perforated Sheet placement & & \\
\hline 8 & Plate spring setting & & \\
\hline 9 & Core pressing & $10: 00$ AM to 11:00 AM & \\
\hline 10 & Station to fixture for filter cup part 2 assembly & $11: 30$ AM to 11:30 AM & \\
\hline 11 & TIG Welding \& Inspection & $11: 30$ AM to 12:30 PM & \\
\hline 12 & TIG welding fixture to plasma welding placement & $12: 30$ PM to 12:45 PM & \\
\hline 13 & Plasma welding \& Inspection & & \\
\hline 14 & Plasma welding fixture to leak test machine station & \\
\hline
\end{tabular}




\begin{tabular}{|l|l|l|l|}
\hline 15 & Leak testing \& Inspection & 1:00 PM to 2:00 PM & \\
\hline 16 & Leak testing station to pallet arrangement & & $10: 00$ AM to 10:30 AM \\
\hline 17 & Cap fitting & & $10: 30$ AM to 11:30 AM \\
\hline 18 & Filter cup from pallet to fixture & & 11:30 AM to 12:30 AM \\
\hline 19 & Flare and connector cap fixing & & \multirow{2}{*}{ 12:30 PM to 12:45 PM } \\
\hline 20 & Sticker and silica gel insertion & & $1: 00$ PM to 2:00 PM \\
\hline 21 & Packaging in separate boxes & & \\
\hline 22 & Industrial Packaging & & \\
\hline
\end{tabular}

Table 3. Second shift time study time table

\begin{tabular}{|c|c|c|c|}
\hline S.No & Activities & 06-02-2017 & 07-02-2017 \\
\hline 1 & Washing Machine feeding (Pallet to conveyor) & 2:00 PM to 3:00 PM & 2:00 PM to 3:00 PM \\
\hline 2 & Connector ring fitting and connector insertion on the cup & 3:00 PM to 4:00 PM & 3:00 PM to 4:00 PM \\
\hline 3 & Dummy Ring Placement & 4:00 AM to 4:08 AM & 4:00 AM to 4:08 AM \\
\hline 4 & Cups removal from the furance and placement in pallets & 5:00 PM to 6:00 PM & 5:00 PM to 6:00 PM \\
\hline 5 & Filter cups from pallet to fixture & \multirow{6}{*}{$4: 10 \mathrm{PM}$ to $4: 45 \mathrm{PM}$} & \multirow{6}{*}{ 4:10 PM to $4: 45 \mathrm{PM}$} \\
\hline 6 & Wire mesh + Felt mat insertion & & \\
\hline 7 & Perforated Sheet placement & & \\
\hline 8 & Plate spring setting & & \\
\hline 9 & Core pressing & & \\
\hline 10 & Station to fixture for filter cup part 2 assembly & & \\
\hline 11 & TIG Welding \& Inspection & 7:00 PM to 8:00 PM & \\
\hline 12 & TIG welding fixture to plasma welding placement & 8:00 PM to $8: 30 \mathrm{PM}$ & \\
\hline 13 & Plasma welding \& Inspection & $8: 30 \mathrm{PM}$ to $9: 30 \mathrm{PM}$ & \\
\hline 14 & Plasma welding fixture to leak test machine station & 9:30 PM to 9:45 PM & \\
\hline 15 & Leak testing \& Inspection & 10:00 PM to $11: 00 \mathrm{PM}$ & \\
\hline 16 & Leak testing station to pallet arrangement & & 7:00 PM to 7:30 PM \\
\hline 17 & Cap fitting & & 7:30 PM to $8: 30 \mathrm{AM}$ \\
\hline 18 & Filter cup from pallet to fixture & & \multirow{2}{*}{ 8:30 PM to 9:30 PM } \\
\hline 19 & Flare and connector cap fixing & & \\
\hline 20 & Sticker and silica gel insertion & & \multirow{2}{*}{ 9:30 PM to 9:45 PM } \\
\hline 21 & Packaging in separate boxes & & \\
\hline 22 & Industrial Packaging & & 10:00 PM to 11:00 PM \\
\hline
\end{tabular}

Table 4. First shift time study data

\begin{tabular}{|c|l|l|l|l|l|l|}
\hline S.No & Activities & $\mathbf{3 0 - 0 1 - 2 0 1 7}$ & $\mathbf{3 1 - 0 1 - 2 0 1 7}$ & $\mathbf{0 1 - 0 2 - 2 0 1 7}$ & $\mathbf{0 2 - 0 2 - 2 0 1 7}$ & $\mathbf{0 3 - 0 2 - 2 0 1 7}$ \\
\hline 1 & Washing Machine feeding (Pallet to conveyor) & 4.0404 & 4.0584 & 4.5163 & 4.1671 & 4.4894 \\
\hline 2 & $\begin{array}{l}\text { Connector ring fitting and connector insertion on } \\
\text { the cup }\end{array}$ & 3.0134 & 3.0284 & 2.9865 & 3.0083 & 3.0142 \\
\hline 3 & Dummy Ring Placement & 366.0000 & 376.0000 & 350.0000 & 390.0000 & 358.0000 \\
\hline 4 & Cups removal from the furance and placement in & 4.5044 & 4.5118 & 4.4712 & 4.4699 & 4.4791 \\
\hline
\end{tabular}




\begin{tabular}{|c|c|c|c|c|c|c|}
\hline & pallets & & & & & \\
\hline 5 & Filter cups from pallet to fixture & \multirow{6}{*}{14.9286} & \multirow{6}{*}{14.9571} & \multirow{6}{*}{14.9231} & \multirow{6}{*}{14.8043} & \multirow{6}{*}{15.5956} \\
\hline 6 & Wire mesh + Felt mat insertion & & & & & \\
\hline 7 & Perforated Sheet placement & & & & & \\
\hline 8 & Plate spring setting & & & & & \\
\hline 9 & Core pressing & & & & & \\
\hline 10 & Station to fixture for filter cup part 2 assembly & & & & & \\
\hline 11 & TIG Welding \& Inspection & 5.0381 & & 4.9986 & & 5.0420 \\
\hline 12 & $\begin{array}{l}\text { TIG welding fixture to plasma welding } \\
\text { placement }\end{array}$ & 3.4795 & & 3.3155 & & 3.3083 \\
\hline 13 & Plasma welding \& Inspection & 14.8750 & & 14.5415 & & 15.1787 \\
\hline 14 & $\begin{array}{l}\text { Plasma welding fixture to leak test machine } \\
\text { station }\end{array}$ & 4.0362 & & 3.6816 & & 3.8291 \\
\hline 15 & Leak testing \& Inspection & 14.8410 & & 15.1581 & & 14.8984 \\
\hline 16 & Leak testing station to pallet arrangement & & 3.4932 & & 3.4343 & \\
\hline 17 & Cap fitting & & 3.4496 & & 3.4119 & \\
\hline 18 & Filter cup from pallet to fixture & & \multirow{2}{*}{7.9514} & & \multirow{2}{*}{8.0767} & \\
\hline 19 & Flare and connector cap fixing & & & & & \\
\hline 20 & Sticker and silica gel insertion & & \multirow{2}{*}{4.4724} & & \multirow{2}{*}{4.5187} & \\
\hline 21 & Packaging in separate boxes & & & & & \\
\hline 22 & Industrial Packaging & & 4.5000 & & 4.8333 & \\
\hline
\end{tabular}

Table 5. Second shift time study data

\begin{tabular}{|c|c|c|c|c|c|c|}
\hline S.No & Activities & 06-02-2017 & 07-02-2017 & 08-02-2017 & 09-02-2017 & 10-02-2017 \\
\hline 1 & Washing Machine feeding (Pallet to conveyor) & 4.0202 & 4.0854 & 4.0564 & 4.0608 & 4.0745 \\
\hline 2 & $\begin{array}{l}\text { Connector ring fitting and connector insertion } \\
\text { on the cup }\end{array}$ & 3.0261 & 3.0266 & 3.0067 & 3.1239 & 3.0492 \\
\hline 3 & Dummy Ring Placement & 454.0000 & 467.0000 & 488.0000 & 356.0000 & 389.0000 \\
\hline 4 & $\begin{array}{l}\text { Cups removal from the furance and placement } \\
\text { in pallets }\end{array}$ & 4.4975 & 4.4724 & 4.4845 & 4.5263 & 4.5239 \\
\hline 5 & Filter cups from pallet to fixture & \multirow{6}{*}{15.2500} & \multirow{6}{*}{14.8099} & \multirow{6}{*}{15.4265} & \multirow{6}{*}{14.5862} & \multirow{6}{*}{14.5694} \\
\hline 6 & Wire mesh + Felt mat insertion & & & & & \\
\hline 7 & Perforated Sheet placement & & & & & \\
\hline 8 & Plate spring setting & & & & & \\
\hline 9 & Core pressing & & & & & \\
\hline 10 & Station to fixture for filter cup part 2 assembly & & & & & \\
\hline 11 & TIG Welding \& Inspection & 5.0506 & & 4.9944 & & 5.1605 \\
\hline 12 & $\begin{array}{l}\text { TIG welding fixture to plasma welding } \\
\text { placement }\end{array}$ & 3.5067 & & 3.4824 & & 3.7004 \\
\hline 13 & Plasma welding \& Inspection & 15.2627 & & 14.9664 & & 15.2917 \\
\hline 14 & $\begin{array}{l}\text { Plasma welding fixture to leak test machine } \\
\text { station }\end{array}$ & 3.8067 & & 4.1193 & & 4.0917 \\
\hline 15 & Leak testing \& Inspection & 15.0936 & & 14.7243 & & 16.5094 \\
\hline 16 & Leak testing station to pallet arrangement & & 3.4731 & & 3.4685 & \\
\hline
\end{tabular}




\begin{tabular}{|c|c|c|c|}
\hline 17 & Cap fitting & 3.6545 & 3.5603 \\
\hline 18 & Filter cup from pallet to fixture & \multirow{2}{*}{8.1016} & \multirow{2}{*}{-7.8652} \\
\hline 19 & Flare and connector cap fixing & & \\
\hline 20 & Sticker and silica gel insertion & \multirow{2}{*}{4.4776} & \multirow{2}{*}{-4.6667} \\
\hline 21 & Packaging in separate boxes & & \\
\hline 22 & Industrial Packaging & 4.3333 & 4.8333 \\
\hline
\end{tabular}

Table 6. Consolidated time study data

\begin{tabular}{|c|l|l|l|l|}
\hline S.No & Activities & First Shift (S) & Sec Shift (S) & Cons Time (S) \\
\hline 1 & Washing Machine feeding (Pallet to conveyor) & 4.25 & 4.06 & 4.16 \\
\hline 2 & Connector ring fitting and connector insertion on the cup & 3.01 & 3.05 & 3.03 \\
\hline 3 & Dummy Ring Placement & 368.00 & 430.80 & 399.40 \\
\hline 4 & Cups removal from the furance and placement in pallets & 4.49 & 4.50 & 4.49 \\
\hline 5 & Filter cups from pallet to fixture & & & \\
\hline 6 & Wire mesh + Felt mat insertion & & & \\
\hline 7 & Perforated Sheet placement & 15.04 & 14.93 & \multirow{2}{*}{14.99} \\
\hline 8 & Plate spring setting & & & \\
\hline 9 & Core pressing & & & \\
\hline 10 & Station to fixture for filter cup part 2 assembly & 5.03 & 5.07 & 5.05 \\
\hline 11 & TIG Welding \& Inspection & 3.37 & 3.56 & 3.47 \\
\hline 12 & TIG welding fixture to plasma welding placement & 14.87 & 15.17 & 15.02 \\
\hline 13 & Plasma welding \& Inspection & 3.85 & 4.01 & 3.93 \\
\hline 14 & Plasma welding fixture to leak test machine station & 14.97 & 15.44 & 15.20 \\
\hline 15 & Leak testing \& Inspection & 3.46 & 3.47 & 3.47 \\
\hline 16 & Leak testing station to pallet arrangement & 3.43 & 3.61 & 3.52 \\
\hline 17 & Cap fitting & 8.01 & 7.98 & 8.00 \\
\hline 18 & Filter cup from pallet to fixture & 4.50 & 4.57 & 4.53 \\
\hline 19 & Flare and connector cap fixing & 4.67 & 4.58 & 4.63 \\
\hline 20 & Sticker and silica gel insertion & & \\
\hline 21 & Packaging in separate boxes & & \\
\hline 22 & Industrial Packaging & & \\
\cline { 1 - 2 } & & & \\
\hline
\end{tabular}

Table 7. Time study comparison with company standards

\begin{tabular}{|c|l|l|l|}
\hline S.No & Activities & Std Time (S) & Time Study (S) \\
\hline 1 & Washing Machine feeding (Pallet to conveyor) & 3 & 4.16 \\
\hline 2 & Connector ring fitting and connector insertion on the cup & 2 & 3.03 \\
\hline 3 & Dummy Ring Placement & 300 & 399.40 \\
\hline 4 & Cups removal from the furance and placement in pallets & 4 & 4.49 \\
\hline 5 & Filter cups from pallet to fixture & 12 & 14.99 \\
\hline
\end{tabular}




\begin{tabular}{|c|c|c|c|}
\hline 6 & Wire mesh + Felt mat insertion & & \\
\hline 7 & Perforated Sheet placement & & \\
\hline 8 & Plate spring setting & & \\
\hline 9 & Core pressing & & \\
\hline 10 & Station to fixture for filter cup part 2 assembly & & \\
\hline 11 & TIG Welding \& Inspection & 5 & 5.05 \\
\hline 12 & TIG welding fixture to plasma welding placement & 2 & 3.47 \\
\hline 13 & Plasma welding \& Inspection & 12 & 15.02 \\
\hline 14 & Plasma welding fixture to leak test machine station & 3 & 3.93 \\
\hline 15 & Leak testing \& Inspection & 12 & 15.20 \\
\hline 16 & Leak testing station to pallet arrangement & 2 & 3.47 \\
\hline 17 & Cap fitting & 2 & 3.52 \\
\hline 18 & Filter cup from pallet to fixture & \multirow{4}{*}{-3} & \multirow{2}{*}{8.00} \\
\hline 19 & Flare and connector cap fixing & & \\
\hline 20 & Sticker and silica gel insertion & & \multirow{2}{*}{4.53} \\
\hline 21 & Packaging in separate boxes & & \\
\hline 22 & Industrial Packaging & 5 & 4.63 \\
\hline
\end{tabular}

\section{Conclusions}

The process flow required for the filter drier manufacturing has been found out according to the production sequence. The set of activities for the different assembly process are laid out for the time study calculation. Assumptions and ground rules have been according to the basic time study calculations for the filter drier manufacturing process. Time study has been done using standard time chart and electronic stop watch with $4 \%$ allowance. From the final time study analysis, it is found that the importand operations such as 1.) Dummy ring placement in the furnace 2.) Filter cup assembly 3.) Plasma welding and inspection 4.) Leak testing and inspection

1.) Filter cup to pallet fixture and 6.) Flare connector cap fixing have not been performed on the Standard time chart as fixed by the company norms. The annual requirement for the filter drier production is 80,000 . Monthly requirement is 6668 with 26 days working day. Considering this, per day requirement is 256 according to the production standards maintained by the company.

From time study, we have found that there are major devtations with standard time in dummy ring placement, filter drier assembly, plasma welding, leak testing and filter package section. Due to this practice, the production per day has reduced to 228 . We have found the major setbacks in the productivity using the time study, once the standard time is followed in the respective workstations; we can achieve the actual requirement of 256 filter driers per day. 


\section{References}

[1] B. Naveen et al. "Productivity improvement in shoe making industry by using method study", IOSR Journal of Mechanical and Civil Engineering, 2015.

[2] Noriah Yusoffa et al. "Work Measurement For Process Improvement In The Car SeatPolyurethane Injection Manufacturing Line", Elseqvgier, 2012.

[3] Parthiban.et al. "Productivity improvement in shoe making industry By using method study", IOSR Journal of Mechanical and Civil Engineering, 2015.

[4] S. Nallusamy et al. "Lean Tools Execution in a Small Scale Manufacturing Industry for Productivity Improvement- A Case Study", Indian Journal of Science and Technology, 2016.

[5] Vivek Agnihotri et al. "Productivity Improvement in Assembly Line of an Automobile Industry", IOSR Journal of Mechanical and Civil Engineering, 2015.

[6] S. Suhas, M.J. SilvisterRaju, D.S. Vijayan, "Natural fibre reinforcement experimental study in polymer composite", Materials Today: Proceedings, , https://doi.org/10.1016/j.matpr.2020.12.051

[7] LavanyaPrabha, S., J. K. Dattatreya, and M. Neelamegam. "Investigation of bolted RPC plate under direct tension." Journal of Structural Engineering (Madras) 36.5 (2009): 333-341.

[8] M. Tholkapiyan, A.Mohan, Vijayan.D.S , "A survey of recent studieson chlorophyll variation in Indian coastal waters", IOP Conf. Series: Materials Science and Engineering 993 (2020) 012041, doi:10.1088/1757-899X/993/1/012041. 